Findings are presented from a study of 43 advanced professional school students in law and business using in-depth interviews to investigate their orientations to work and family life. Thematic types are developed that identify the orientations of segments within the sample. These types draw on respondents' implicit and explicit definitions of the situation, paying special attention to key assumptions about gender-based work and family roles. Interestingly, the findings indicate a certain degree of asymmetry between the men and the women with respect to how they plan to construct work and family life. The dominant segment of men identified strongly with a modified form of providing, whereas others identified with either a strong or a weak form of egalitarianism. The dominant segment of women were oriented toward a strong form of egalitarianism, with others oriented toward a weak form of egalitarianism, and still others considered remaining single a realistic possibility.

\title{
Aspiring Law and Business Professionals' Orientations to Work and Family Life
}

\author{
ROBERT M. ORRANGE \\ Eastern Michigan University
}

What kinds of work-family blueprints will aspiring professionals in our society carry with them into the 21 st century? This article presents findings from in-depth interviews that examined the work-family orientations of a sample of advanced professional school students in law and business. In so doing, it provides a glimpse into the lives of those who represent future members of the professional and managerial sectors of the middle class, a segment of society that wields power within formal organizations and plays an important role in shaping political and cultural debates throughout the broader society (Lamont, 1992). The respondents in this study are in their mid- to late 20s and about to launch careers; these characteristics reflect an anticipatory stage in the life course. Their definitions about the near-term future, which reflect ongoing tensions between their hopes and expectations, represent a framing context out of which their

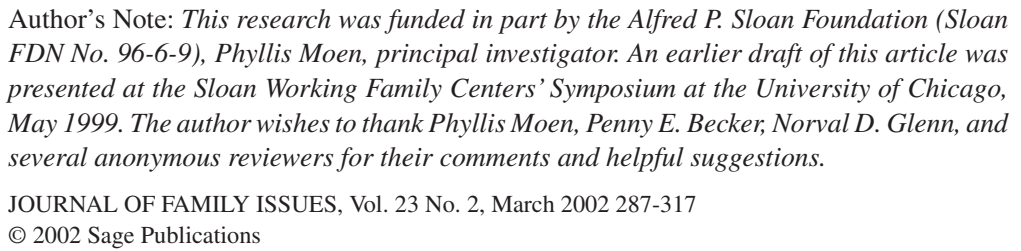
FDN No. 96-6-9), Phyllis Moen, principal investigator. An earlier draft of this article was presented at the Sloan Working Family Centers' Symposium at the University of Chicago, May 1999. The author wishes to thank Phyllis Moen, Penny E. Becker, Norval D. Glenn, and several anonymous reviewers for their comments and helpful suggestions.

JOURNAL OF FAMILY ISSUES, Vol. 23 No. 2, March 2002 287-317

(C) 2002 Sage Publications 
lives will unfold. Moreover, these men and women are formulating their work and family plans within the context of a potentially shared marriage market, in that many of them will likely be dating others who have similar backgrounds. We know little about the plans and expectations of the men and women who are part of the generation of post-baby boomers.

Although the research herein was originally crafted around a number of interrelated theoretical issues related to a changing sociohistorical context, such as the long-term rise of individualism, ${ }^{1}$ the end of lifetime careers in corporate America, ${ }^{2}$ the gender revolution, and the rise of dualearner couples, the latter two were most relevant to framing this particular study. ${ }^{3}$ During the past few decades, many women have recast their work and family roles, as have men, albeit far more slowly. This research demonstrates the complex and permeable ways that both men and women think about their roles as they struggle over traditional versus egalitarian conceptions about work and family life. Furthermore, many of these aspiring professionals will likely become partners in dual-career marriages, and the extent to which they envision living this lifestyle means that they will need to cope with a number of significant issues surrounding the demands of work and family life over time.

\section{RECASTING WORK AND FAMILY ROLES}

Women in professional schools today have benefited from an expanded range of lifestyle options made possible by the gender revolution. Choices such as remaining single or childless, or even living with a partner outside of marriage, are generally tolerated (Cancian, 1987). These women have also come of age during a time in which it is common for women to be in the paid labor force during all phases of adult life leading up to retirement, even during those times when they have young children (Moen, 1992). Therefore, given these expanded options, it seems unlikely that the lives of these women will conform to one homogeneous template. Instead, their life trajectories may follow a diversity of pathways (Gerson, 1985).

Due to the high levels of women's labor force participation, dualearner couples have become the norm in U.S. society, with more than $60 \%$ of married women with children under age 6 in the paid labor force as of the mid-1990s (Han \& Moen, 1999). Members of dual-earner or dual-career couples confront considerable challenges, such as balancing considerations about when and whether to have children with employment or career demands. They must also negotiate how to divide the labor of the second shift (Hochschild, 1989), or the household work and child care that 
must be accomplished after the paid workday is ended. And although couples must jointly manage these two demands, overall responsibility for family life is still regarded as a women's issue in American society, as women still bear a disproportionate share of their families' household and child care responsibilities (Moen, 1992; Shelton \& John, 1996; Spain \& Bianchi, 1996). Therefore, many women feel pressure to make choices between career and family, whereas men do not (Bielby \& Bielby, 1989).

The gender revolution has not simply affected the lives of women, however; it has also affected the work and family strategies of men, albeit much less dramatically. Some men have even found alternative means of coping with changing relationship obligations, such as sharing both family responsibilities and career sacrifices more fully with their wives or, alternatively, eschewing commitments altogether (Gerson, 1993). Nonetheless, the good-provider role (Bernard, 1981) remains of special interest to work and family scholars. Although this role has been difficult to examine empirically (see Hood, 1986), the extent to which couples embrace the male provider role greatly affects how they negotiate other areas of their relationship. Schwartz (1994) has found that strong adherence to the provider role represents a major obstacle to couples' forging egalitarian relationships, particularly due to their reliance on the enhanced income and financial security that it can supply. Furthermore, Schwartz emphasizes that even for couples who are committed to having egalitarian relationships, too much of an imbalance in the division of labor-favoring a traditional breadwinner-homemaker model—leads to a hierarchical relationship favoring the breadwinner, and transforms peer relationships into near-peer ones. This is true despite evidence that providers have begun to embrace more "nurturant dimensions of parenting" or involved fathering (Cohen, 1993, p. 20). ${ }^{4}$

The advanced professional school students in this study have formed their plans and aspirations for the future amid ongoing debates in both the popular and academic press about the viability of the dual-earner couple. ${ }^{5}$ Conflicting accounts suggest that on one hand, dual-earner couples are caught in a pervasive time bind, the pangs of which they feel particularly sharply at home, and in response, they have looked to the workplace as a refuge from their hectic lives (Hochschild, 1997). Unfortunately, this solution tends to exacerbate the problem of time scarcity at home. On the other hand, dual-earner couples have been portrayed as having happier, healthier, and more satisfying family lives, while they also enjoy the increased financial security of having two paychecks (Barnett \& Rivers, 1996). A third view finds members of dual-earner couples (mostly wives) scaling back their commitments to work to create a buffer for the family 
(Becker \& Moen, 1999). In a somewhat related vein, a recent study of the American middle class by Alan Wolfe (1998) indicates that many Americans feel ambivalent about the impact that the dual-earner lifestyle has had on their own lives and those of their families, even as they acknowledge having no plans of going back to some imagined past.

\section{DEFINING THE FUTURE}

Because family responsibilities are commonly associated with women, we might expect that men and women will think about the relationship between their future work and family roles differently. In fact, Andrews and Bailyn (1993) found, in their follow-up study of Wallace's (1989) research on MBAs, that men and women do think about work and family life through very different sets of categories, and these either tend to limit or enhance the possibilities for coping with the demands of both spheres. Andrews and Bailyn found that most men defined the relationship between work and family by using a model of segmentation, which implies that the two areas are separate and distinct. In contrast, women employed a model based on synergy, which implies that the two areas are interconnected and interdependent. Given these models, the men were less open to and aware of the possibility that adjustments could be made in one realm (i.e., work) that would enhance their ability to negotiate both. The women, on the other hand, tended to think about and make plans for either work or family life with the guiding assumption that the realms were highly interdependent (Andrews \& Bailyn, 1993). These findings are reinforced by Pleck's (1993) study, which found that men were far more likely to use informal arrangements as opposed to formal policies at work to take care of family responsibilities, because they were concerned that others might question their organizational commitment.

The concepts of segmentation and synergy used by Andrews and Bailyn (1993) have implications for the ways in which young adults conceptualize their life plans for work and family, in that these two concepts can be linked to the awareness contexts that serve as orienting frames of reference for those plans. In fact, more than a decade ago, Maines and Hardesty (1987) found among university students that men tended to think about their futures in linear terms, focusing on careers while not concerning themselves with family responsibilities. Furthermore, Maines and Hardesty found that women tended to have more contingent definitions of their futures, with concerns about family life eroding their commitments to pursuing careers. 
By investigating the plans and aspirations of these professional school students, we can examine whether tensions exist between their hopes and expectations for the future and how these affect their overall orientations to work and family roles. Although the future is not a fact, an individual's definitions of the future represent shaping influences on the trajectory of life experiences that follow from those definitions. For what we define, acknowledge, confront, or anticipate with respect to our own future provides a framework for action; and so, if researchers seek to understand how couples negotiate work and family roles, it is important to see how these are set up or framed in advance (but not determined). To an important extent, the strategies for adaptation (Moen \& Wethington, 1992) that couples employ to negotiate work and family life exist as potentials for action during an earlier or anticipatory stage in the life course.

The analysis that follows will address the question of how men and women who are soon to enter the ranks of the professional middle class define their life plans for work and family life. It will examine the interplay between their hopes and expectations in shaping their orientations to work and family life.

\section{SAMPLE AND METHODS}

This research draws on an in-depth study of 43 advanced professional school students in law and MBA programs at a major research university in the southwestern United States. The majority of the respondents were between 24 and 29 years of age. In addition, all but 7 of the men and 3 of the women were single (not married). There were 11 men and 10 women from the law school, 12 men and 6 women from the business school, and an additional 4 respondents ( 3 men and 1 woman) from a joint program between law and business. All respondents were recruited using snowball sampling techniques, whereby an initial set of respondents was recruited through various entry points into the law and business schools, and then contacts for subsequent interviews were obtained through respondents themselves, and so on.

One overarching goal of this research was to examine how members of the more privileged sectors of our society define issues related to work and family life. These law and MBA students-who are in an anticipatory stage (Becker \& Moen, 1999) of the life course and soon to form families and embark on careers - represent future members of the professional and managerial sectors of the middle class, a highly influential segment of the 
population. This segment of the middle class plays an important role in shaping political and cultural debates throughout the broader society, not to mention the power they wield within formal organizations (Lamont, 1992).

Each respondent was interviewed using a set of guiding questions that revolved around defining one's life plans for work, family, and leisure. The questions were focused on how, and to what extent, respondents defined each life domain, as well as the interrelationships between them. Moreover, probes and follow-up questions were employed to capture each respondent's definition of the situation. All interviews were taped for transcription and analysis. Analysis involved examination of the interviews for a series of dominant and subdominant themes, which were then used as the basis for constructing a typology of orientations to work-family life. The typology presented identifies majority and minority segments of the sample, with the majority typically referring to about two thirds of respondents in a given category. However, caution should be used in interpreting these findings as highly representative of some well-defined population in the broader society, for the research involved a purposive sample of 43 respondents. ${ }^{6}$

\section{FINDINGS}

As a general rule the men and the women in this study discussed their plans for work and family life in somewhat asymmetrical fashion. The dominant orientation for the men revolved around providing for their families, yet not necessarily in a strict or narrow sense. These men also valued the expressive side of family life. However, given their predominantly linear and segmented definitions of work and family life, they ranged from explicitly adamant to hopefully ambivalent about finding marriage partners who would take primary responsibility either for raising children or ensuring that they are well cared for and managing the household. In contrast, most of the women aspired to find partners with whom they could forge egalitarian relationships and thus more fully share in taking advantage of career opportunities and handling family responsibilities. Many were ambivalent about their prospects. Furthermore, another minority segment of respondents, both men and women, embraced what I term a weak form of egalitarianism in which they envisioned sharing both career opportunities and family responsibilities to a large extent with their partners, except for that period of time when young children are in the picture. 
During this time, they expect to shift into more traditional breadwinner/ homemaker roles. Unfortunately, weak egalitarianism holds potentially deleterious implications for the career prospects of the women but not the men. In addition, there was another minority segment of male respondents who aspired to find marriage partners with whom they might forge relationships that would be more thoroughly egalitarian. Furthermore, a minority segment of strong egalitarian women discussed remaining single as a realistic possibility for them, whereas only a few of the men discussed remaining single. In fact, I found very few avoiders (see Gerson, 1993) among the men. Finally, it should be emphasized that few of the men and women portrayed in the following sections represent ideologically pure types. In fact, a number of them conveyed a certain measure of ambivalence about their scenarios for the future, much of which seems generated by their struggles to cope with tensions between their hopes and expectations.

\section{MEN: PROVIDERS}

For a dominant segment of the men, breadwinning or providing was a very important part of their definition of the future, which in turn served to shape their definition (however vague) of what they were looking for in a spouse and family life in general. Of all the respondents, these men had the most linear and segmented definitions of their own career trajectories. They seemed to embrace modified versions of providing, however, at least, as it is understood in the strictly traditional sense. For many of them, finding a spouse who would take charge of the household and child-rearing activities seemed very important. More specifically, a number of these men expected to leave decisions about working outside of the home to their wives' discretion, just as long as arrangements were made, such as finding child care and house cleaners, so that family life would be taken care of. However, many of these men did not view providing as their sole contribution to family life. Instead, they seemed to place a great deal of value on the expressive side of relationships with wives and children (see Cohen, 1993). Furthermore, few of these men defined their work-family orientations in overtly traditional ways. Instead, some seemed hesitant about making such revelations, as if they were actively conscious, and even supportive in the abstract, of more recent egalitarian ideals, such as the rights of women to pursue careers. However, they had the tendency to back away from their ideals the more they confronted their expectations about the future, thus conveying a good deal of ambivalence. 
One MBA student who was married, soon to graduate, and had accepted a job offer with a major investment firm, discussed how he was supportive of his wife working and even pursuing a career:

I would love to see her work. I think that would be great. She is not going to be a big corporate attorney or anything like that. You see, she is politically active and so seems to be more interested in lobbying.

We then discussed the kinds of working arrangements they would most likely forge when children enter the picture, and he mentioned how he envisioned himself being the breadwinner. He felt that his wife could still work just as long as family life was taken care of:

When we have kids, I honestly see us moving toward more traditional worker and homemaker roles. But also, in her family, there has always been help-a live-in or a baby-sitter. If she had a job that is very career oriented and required some time away from the family every day, we could move to that very easily. I'll probably always be the so-called breadwinner. What I would like is for her to have a lot of options. That we can both agree upon, because I'll work, and I'll enjoy my job, and if it's as rosy as I plan it to be, then I'll be able to do a lot of things, and we'll be able to do a lot of things as a family. But I would like her to have the option, you know, if she wants to stay home and take care of the kids, more power to her. But, if she wants to work and get some help until they're old enough to take care of themselves, we can do that, too. Whatever she wants to do, I would support her, but at the same time realizing that the family would be the most important consideration.

Similarly, another aspiring professional, a law student who was soon to be engaged to his girlfriend, said that she would most likely work and, perhaps, have a career but that he ultimately envisioned himself being the breadwinner. He discussed his wife's aspirations:

I don't think she will want to stay at home all the time, or even for too long after having children. She wants to get her master's in public policy and administration and then maybe work in a nonprofit agency. Personally, I don't imagine myself being a house-husband, or running a legal office out of the house and staying at home with the kids. That does not seem to be an option to me. But you can't rule anything out; if the need arose, if it had to happen, then we could always make arrangements and do something to have one of us at home all the time.

When asked about whether he and his wife would need help raising the kids or with housework, he noted, 
I think we will be financially able to do what is needed. I'd never really considered a nanny or some type of live-in help. In fact, when you mentioned someone to help, I just immediately thought of my parents or some combination of our parents, whomever is close by. I guess day care would be OK if, once again, it's highly selective. I would always want the best for the kids, you know, all the general parenting concerns.

Maybe some of this will depend on what your wife ends up doing?

Right. I would prefer, I think, to be able to structure something, even if we had to, or she took a pay cut or if she took a different job-something she could do out of the house, which I think would be . . .

That would be the ideal, maybe?

Yeah.

Although he seemed somewhat ambivalent about his wife working outside of the home on a full-time basis whenever children enter the picture, he described his strong commitment to family-like his father before him-in the manner of a good provider. The following passage highlights how providing (besides being associated with status and privilege) represents a moral category once reinforced by a more traditional view of the relationship between the sexes:

I guess if I were unhappy at a job, I'd suck it up and just say "hey, I'll just compartmentalize my life." I mean, my dad was a salesman, and it's not that he loved being a salesman, but he had two kids. And so, it was time to take care of his kids, and that is what he did, and he was able to make a good living at it. So, for me, it would be the family driving the work concerns. Always being the provider.

However, some other men who identified with providing were fairly adamant that their future wives would stay home whenever young children come into the picture. In fact, one of the men in the MBA program, whose wife was actually working on an advanced professional degree, made it clear that he planned to be the sole provider in his family. He did so during our discussion of the kind of salary he hoped to garner after working for 5 years or so.

I'd like to think that within 5 to 7 years, I'd be making six figures, just because I'd like my wife to be able to stay home with our kids, and to do that I need to command that kind of salary.

His career plans were focused around providing for the family, whereas he defined his wife's occupational plans as being driven by concerns about running the household and caring for children. 
She will be getting her [names professional degree] this fall, and so she may be doing some [contract work] at home. What she would ideally like to do is maybe teach when the kids get old enough. I'd say, we will have two kids, maybe 2 years apart — that would be 7 years she was at home maybe doing some [contract work].... She would eventually like to go back to school and teach, eventually at a university or college level, [and] teach on a schedule similar to that of our kids. So, maybe in a high school or vocational school program-something like that where she gets to use skills she already has, and yet be able to maintain a schedule similar to that of our children.

An issue emerged in some of my discussions with men who identified strongly with providing more as a form of status and privilege than as a moral commitment. It involved a clear discrepancy between what they found desirable in a future spouse and the kind of roles they aspired to negotiate within the family. Furthermore, these men seemed to be grappling with this predicament, yet not fully reflective about it. One MBA student, who discussed how he planned to either pursue a career in consulting or marketing after graduating, envisioned that he would most likely have to work long hours and travel frequently during the first few years out of school. Given his intense work habits and strong desire to be successful, he discussed his vision for marriage and family:

This [represents] a sad state of affairs because I have my ideas about what I've learned from my past [relationships] and that is I will have [to marry] somebody who will be very accommodating [to his work habits]. I hate to say it, but it's going to be the traditional male-female roles. I mean, I don't think there is any way around it because I would like to have children. I have a tough time realistically thinking that it's going to happen in any other situation than somebody staying home and watching the kids.

He then discussed his attraction to professional women, which left him somewhat conflicted about how his plans will all work out in the end.

Now, having said that, I'm very attracted to the professional career woman [who] knocks your socks off. Well, this is a stereotype, but successful women are attractive women, OK. I've done a very impromptu study and, you know, the women who make it in the business world are usually attractive. And, for me, I have an unrealistic fixation on looks. . . . And, I'm going to have a tough time finding the mix that I want. I don't know how it's going to come out. [Makes an aside] It will be interesting to hear what you're going to say about this. My ideal is a Barbie-doll wife. I want a Barbie-doll wife. Somebody who looks good on my arm and who will do everything for me. And its not going to happen. ... My experience has been: I seek a person of certain educational background and a certain cultural sophistication ... I think it's going to be a tough match to get. 
As will be discussed, the ambivalence that some men experience because they hope to meet successful and attractive career women who will give it all up one day and stay home with the kids is mirrored by some women, who fear that men will not take their career aspirations seriously.

\section{EGALITARIAN MEN: WEAK FORM}

Somewhat in contrast to providers, weak egalitarians represent one minority subsegment of the men interviewed for this project. Although these men did not seem to identify strongly with providing, they seemed destined to shift into traditional work-family roles on having children. Weak egalitarians seemed to subscribe to an implicit rule about work-applied with the exception of those few years when children are very youngindicating that each partner has a right to work in the paid labor force. In addition, time spent in housework should be inversely proportional to the number of hours spent in the paid labor force, such that total work is shared evenly between the two spouses. This, in itself, did not serve to distinguish the men very much from providers, excepting that weak egalitarians seemed to value the potential income that a spouse could bring home-which, in turn, could take some of the burden off of them to provide. Furthermore, these men seemed to take pride in the fact that they considered themselves to be egalitarian and not wedded to outmoded traditional beliefs about gender roles. Also, these men seemed to have more complex or synergistic views than providers about the potential impact that family could have on career and vice versa. Finally, it appears that weak egalitarians, not unlike many providers, sought to find, or had found, spouses who were not too strongly wedded to their own careers. Certain professions are amenable to accommodations for family life by allowing for flexibility, mobility, and/or gaps in employment (i.e., teacher, registered nurse, social worker, physical therapist, school psychologist, and perhaps certain subfields within accounting). Perhaps, such a scenario leaves open the possibility that over time, the relationships they forge with their spouses may shift from peer to near-peer ones, but that remains an open question.

One married MBA student fits the above description rather well. If possible, he would like to embark on a fairly stable career with a large company once he is out of school. He also mentioned that he wants to make a comfortable salary, but does not want to end up in a position that is so demanding that it negatively affects family life. His spouse has a bachelor's degree and is a registered nurse. He pointed out that because they did not 
have children, both were working in the paid labor force and sharing household responsibilities equitably.

She cleans the tub and mops the floors, and I vacuum, do the laundry, the dishes, and sometimes I cook.

So, you really share?

And I don't have any problem with that. I have no problem with her working, and that's not one of these male breadwinner type things. I think that she should contribute her fair share to the finances, too. And she is very lucky in her profession in that she can do that (work) to whatever extent she wants. It's very flexible.

They were planning to have two children and wanted to begin having them in 1 or 2 years. Once they have kids, he noted, "I think she will probably continue working but on a very limited scale for the first 4 years or so. But, I think she will always want to keep a hand in it." When the kids reach school age, he believes she will go back to work, but at the hours of her choosing. So, during the time when the children are young, the couple will adopt more traditional roles with respect to work and family. Once again, his wife's profession fits well with how they have defined their work and family responsibilities over the next 5 to 10 years. But he defined his commitment to working rather differently than the providers in our study, as he discussed how important is was to his wife that he not become too caught up with career pursuits:

She is very adamant that she does not want me to take a job that maybe has a lot of monetary benefits but puts a lot of time constraints on me. And how would you feel about taking a job like that?

Well, I think that my family life is more important than work. So, like I said, if I was single I wouldn't really care, but I really value spending time with her [his wife] more than spending time at work-it gives me a lot more satisfaction. So, I think that's what I would do.

Another MBA student, who was involved with a woman on a professional career track, seemed to fit the strong egalitarian model fairly well, at least in terms of his rhetoric and ideals. However, as will be discussed, he may end up negotiating work and family arrangements someday in a manner that is more reflective of weak egalitarianism in practice, due to the fact that he took a more segmented approach to his own career and family plans yet entertained more synergistic possibilities for a future spouse: "I probably envision more of an egalitarian type of marriage, where there is a lot more participation by both people in both the work responsibilities as well as the family responsibilities." He emphasized that he viewed mar- 
riage as a "partnership" that involves "sharing." However, one of his main concerns about making sacrifices someday to accommodate children surrounded issues of maintaining "financial stability" and supporting the type of "lifestyle" that he and a future spouse would both want to live. This involved considerations about living in the right location, having a certain amount of "material possessions," and being able to "take vacations." These considerations loomed large for him as he considered different scenarios with respect to raising children:

Certainly I would take off time if I felt that financial stability was there and I could live the kind of comfortable lifestyle that I would like to live. However, if I can't live that kind of lifestyle, then I would not be as likely to [take some time off].

He then discussed how he was aware of certain professional women who were able to arrange flexible work schedules to spend time at home with young children (a synergistic approach to career and family) and, in the process of doing so, it seemed as though he was beginning to consider that option himself, for the first time, and moving toward a strong-egalitarian orientation to work and family life:

I think certain people, depending upon their skill set, if they are good enough at what they do, have the flexibility to work from home. And so, that is definitely an option.

It doesn't sound like your career is very amenable to that?

I wouldn't necessarily say that it is. I haven't seen opportunities as a male yet where you have that flexibility, although they may very well exist. I guess, looking at my own experience, I haven't seen a whole lot of that. But, I have seen that situation in a number of cases for women who have had children and continue working out of their home because they were a real integral part of the operation. And there really is, I guess, nothing to suggest that it couldn't be the man who would do that. Certainly, if I could work out that situation I would be happy to do so.

As this case demonstrates, each respondent's orientation toward the future is the product of ongoing interactions or tensions between their hopes and what they perceive are realistic possibilities for action, a process that contains dynamic possibilities.

\section{EGALITARIAN MEN: STRONG FORM}

A handful of these male professional school students personified the strong egalitarian orientation to work and family life. These men, al- 
though committed to their own careers, also demonstrated an awareness and appreciation of the possibility that they will marry and start families with women who will also be pursuing careers. In fact, they seemed to be more interested in marrying career women someday, because it would provide a common base of shared experiences and even financial security. These men claimed that their future spouses should have equal rights when it comes to pursuing careers and that meant accepting housework and child rearing as shared responsibilities between husbands and wives.

One young law student, who had lived through divorce in his own family, was adamant about the importance of marrying a professional with whom he could relate on a professional level as well as share household and family responsibilities equitably. He felt very strongly that both parents in a marriage should strive to make time available for their children, in addition to having good relations with one another. His girlfriend, who could very likely become his fiancée, was also an aspiring professional. He valued the fact that she was a lawyer, in that it allowed them to have shared interests and mutual understandings, as he noted.

I could never marry somebody who is going to be at home, going to be a homemaker, because I've seen that situation with attorneys I have worked for in the past, who have wives that are homemakers, and they do not understand the pressures that are put on their husbands; they do not understand the hours that they have to work.

He then pointed out how dependent both his mother and grandmother were on their husbands, something that he would not wish on any woman.

Just seeing how dependent my mom was on my father and seeing how dependent my grandmother was on my grandfather, because he was the breadwinner. I guess maybe it's just me, but a lot of my friends will say, "My wife's never going to make more money than me." I'm like, I hope my wife makes more money than me. I'll be perfectly happy to stay home with the kids and raise them, if she wants to be the breadwinner. I have no problem with that. But, by both being professionals, I think there's just a lot more you have in common with your spouse. And I think there is a lot less pressure on who is going to bring in the money, if you have two people bringing home paychecks. I think then, if one of you is unemployed or whatever, it's not the end of the world. You know, if she [his future spouse] was the homemaker and I got unemployed, then I think it would be kind of disastrous. And so, if she were a lawyer, she would have some understanding of what I was going through. 
And although he relished the idea of sharing the responsibility for bringing home the family income with a future spouse, he also was concerned about the type of marriage and family life that he aspired to have because he was emphatic about not wanting to have a "latchkey kid" who

knows their nanny better and spends more time with the nanny than their parents. [And having a latchkey kid] is a product of having two professionals in the home, a product that I would be creating if I married a professional, because somebody would have to take care of them.

He then commented on the possibility of either his or his future spouse's having to make a serious sacrifice someday for the sake of the family.

I don't know. I know that I don't want a latchkey kid, but I would not want my wife to give up her job to raise the kids. I mean, yeah, if she wanted to do it, that's fine. But, I see my wife and I having kids and both continuing to be professionals and probably just cutting back our hours. But hopefully, by then we'll both be partners at a law firm somewhere, or be out on our own or something, where we can be our own boss, where we can leave at 5 o'clock and be home and have the family dinner and have the weekends together, too.

In a follow-up conversation that we had at a later date, he still seemed to be dealing with ambivalent feelings about how to negotiate commitments to career and family, as he mentioned that he probably would not want to try for partner in a large law firm because of the excessive number of hours that may be required of him. His feelings of ambivalence were shared to some extent by those women who seek to forge strong egalitarian relationships, albeit with one important difference. There seems to be a lot more of them around than there are men like him. Confronting this reality generates other types of ambivalence for the women, as will be discussed.

Another male professional student, an MBA who was finishing up his degree and specializing in finance, also personified the strong egalitarian orientation to career and family life in that he had a synergistic view of the relationship between the two life domains. Interestingly, his orientation was reflective of how he had incorporated certain pragmatic concerns about meeting family responsibilities into his career plans and aspirations, whereas, in contrast, his remarks seemed to convey ideas about gender equality that were not without certain elements of contradiction. He had recently accepted an offer with a large investment firm in a major city in the Southwest. He interned with this firm during the summer before our 
interview and was highly impressed with the way in which professionals there were able to make accommodations for family life.

[I] saw the lifestyle that some of these people have [and thought:] "Wow, there is a pretty good balance!" People were able to take off and go to their kid's little league games. There was a woman there. She was a mother of three-high up [in the company], and moving on up. She put the nose to the grindstone from 9 to 5 , and she was able to get out of there by 5:30.

He discussed how he envisioned marrying a professional woman and noted that "when kids come into the picture, I have no problem with her, if she wants to stay at work." He then discussed how he and a spouse might negotiate the demands of work and family life after having children.

Maybe child care after the first initial stages. I believe in mother instincts, but I definitely want to be highly involved. I wouldn't mind staying home and watching the kids maybe for a week or so. I guess I'm flexible. I want to be very involved; I don't want to be like, "Honey, she needs changing-go do it!" I want to be changing diapers. I want them to be able to see my face as much as they see hers.

Interestingly, this MBA student demonstrates the fact that not all respondents are pure types, in that he believes in "mother instincts" yet has also incorporated certain considerations into his career plans and aspirations that reflect concerns about sustaining a dual-career marriage. For instance, we also discussed his thoughts about negotiating career opportunities with a future spouse. Although he seemed a bit conflicted about how he might respond, should a future spouse receive a good job offer that involved relocation, he emphasized how he hopes they can share opportunity equitably: "I see it 50-50... The ideal would be where not one of us rockets in their career and one stays back. Both sacrifice a little bit, and maybe not go as high."

He also mentioned that he and some colleagues were considering starting a consulting business at some point in the future, but that he had some concerns about the risks involved in such an endeavor and how it could have a negative impact on family life. Like the few other strong egalitarians among the men, his conceptualizations about his career and family plans were more synergistic than segmented (Andrews \& Bailyn, 1993), as were those of virtually all of the women in the sample. Their career plans were not defined as separate and distinct from family life but instead reflected scenarios in which their activities and commitments within each realm would affect the other in complicated ways. 


\section{EGALITARIAN WOMEN: STRONG FORM}

The dominant work-family orientation among the women was toward a strong form of egalitarianism. Because of their commitments to career, many of these female law and business students felt it essential that they find partners who would be willing to share responsibility for the household and family life. Most were not terribly optimistic about finding such partners, however, and many seemed to be actively entertaining either a weak egalitarian relationship or remaining single as a fallback position. Ambivalence, either about making a serious commitment to a career or trusting that a future spouse would show equal concern and respect for their plans and aspirations, was not uncommon among these women. None of these women took "having it all," a catchphrase of the 1980s, for granted; they were far more cautious in defining their life plans. In fact, they actively struggled with tensions between their hopes and expectations.

One law student who planned to marry and be working for a large law firm within 5 years of our interview indicated that she had definite standards with regard to a marriage partner. She wanted to find a partner who would achieve status and success within his chosen field, similar to the high standards that she has set for herself, and who also would be willing to share family and household responsibilities equitably. She expected to have at least one and probably two children within 10 years. When asked whether she had certain standards for a future spouse when it comes to work and family responsibilities, she strongly replied,

Very definite standards [laughs]. Well, I am interested in marrying someone successful, and they are really going to have to help out half! And, whatever their strengths are ... [provides an example] I mean, I'm not terribly mechanically oriented, so if they are, then they can fix the lawnmower. But if they can't, they can have someone come and fix it. I mean I can handle everything.

When asked which of these two criteria, being successful or being willing to take on family responsibilities, was more important in a husband, she replied, "I need both, both. I know it's such a tall order." She spoke with a real awareness that her plans for having a successful work and family life were fragile, emphasizing that scheduling having children such that her career does not suffer is "going to be difficult." She would certainly require good fortune and good timing, as she discussed working for about 5 years with a large firm and then taking some maternity leave to begin retooling for a career change, so that she could move into business consulting. Although she hoped that she would not have to sacrifice career for 
family life, she said, "If it comes down to it, I'll sacrifice the career." She exemplified the tensions many of these women experienced between their hopes and expectations for the future, in that she was charting a career path based on a scenario of how she hoped her life would unfold, yet she anticipated that those hopes might not be realizable.

A number of these professional school women hoped to find partners who would be willing to share work and family responsibilities fully or equitably with them; yet, many did mention that they might have to settle for a spouse who would help out or share family responsibilities with them only to a limited extent. Certainly, it is one future situation that is hard to define, as one woman described her preferences for the type of relationship she would like to have with a spouse someday as "definitely nontraditional," but her realistic expectations were somewhat different (somewhat reflective of weak egalitarianism).

I anticipate, my preference would be that both myself and my husband would want [to take] time off and would want to share, although I anticipate still with a lot of men, [they] consider the woman to be more of the caretaker. I expect particularly with my fiancée, [that] he will choose to be less involved, and that frustrates me a little bit and was something I considered long and hard when we started talking more seriously [about marriage]. But, I've come to expect that. It is hard to find a good man who really wants to be involved with the children to the extent that you would expect yourself to be. And so, I don't expect that. And, maybe that's more reflective of my more traditional opinions.

Or, of a reality?

Or of a reality. The way it is. I have dated people or been exposed to people in the past where I was like "they would be a good father; they would be the kind of father I would ideally choose." But, you can't always choose the best partner for every aspect [of a relationship]. So, I anticipate that I will be more of the caretaker and will have more of a role in [rearing] children.

Like other women in this study, she aspired to be highly successful in her chosen field so that when the time comes to start a family, she will have the power to negotiate a flexible schedule of her own choosing with her employer.

I'm a very hard worker, and I'm definitely a workaholic. I have this kind of problem where if I' $m$ in a [certain] position, I will do the work and I will enjoy it ... to the detriment of everything else in my life.... I think that the big breaking point is going to be when I decide to have children. I'm willing to kind of work hard up until that point. ... [But] I've known other people who have had positions I'd love to be able to emulate where they've worked hard, they've gained a reputation, and so now they can design their own 
work arrangements, [such as] working from home part of the time. I'd like to be in that position when I decide to have children.

Another MBA candidate defined her work-family plans such that there was a significant discrepancy between the ideal and the real or the possible. She desired to marry a professional because, as she noted, "I expect my career to be demanding, and somebody has to do that [be a professional] to understand that." Thoughts about family life certainly were making the process of deciding which career path to take a complicated one. She emphasized, "I think the biggest problem for me is relocation issues, because I see myself being in a two-career family someday." In discussing the kind relationship model she envisioned developing around work and family life, she noted, "I think it most likely would be dual everything [career and household responsibilities]." She imagined a life in which both she and a future spouse would be able to share the demands of family life while maintaining their careers, but she was not very hopeful that such arrangements could be made in practice.

If I could find two careers where my husband and I could rotate-you know, take 2 years sabbatical, then work for 2 years-I [would] have no problem going to work and having him be the "Mr. Mom." That would be perfectly fine. I wouldn't want it to be that way all the time, because I want to be at home with my kids [some] of the time.... [She then comments on the scenario] But I think it's unrealistic.

When many of these strong egalitarian women discussed their plans for work and family life, one overriding concern seemed to be that they did not fully trust that their future husbands would be willing to share career opportunities and family responsibilities in an equitable manner-that the men might instead renege on the deal. One law student discussed how important it was to her that a future spouse be willing to make sacrifices in his career for her, as she was prepared to do the same for him. Not that he would have to do so, but she emphasized how she needed to trust that he would be willing to do so. In fact, she seemed open the possibility of having a relationship that would be more reflective of weak egalitarianism in practice.

Ideally, I'd like [for us to have] shared roles, just because I plan to be working, too. And, if I wasn't working, then I could see a justification for me having to be the one taking on the family role and raising children, if any, or keeping up the house. You know, but if I'm going to be working, too, then I think of it as sort of a shared responsibility that we have. 
She then discussed the possibility that some day either she or her future spouse would make sacrifices for the other's career.

On the one hand, I'd be willing to sacrifice if my spouse had an opportunity. But, I would expect the same type of thing from him, you know, if I had some glorious opportunity. . . . I would just expect mutual sacrifice and compromise rather than one-sided sacrifice. But, I would definitely be willing to sacrifice work for family. ... I would hope that [my future spouse] would be willing to [sacrifice also]. Not that they'd have to, necessarily. I wouldn't make them make a sacrifice for the sake of making a sacrifice, just to prove that to me. But I would definitely have to feel that I was, and the family was, a priority.

Finally, she discussed how her thoughts about work and family life were influenced by her mother, whom she viewed as being too invested in the lives of her children, which seemed to make it difficult for all of them growing up. This is what Hochschild (1989) refers to as a cautionary tale from childhood.

One of the things I saw in my family was my mom didn't work [while we were] growing up, and so we were her life and that was it. So now, if she feels like she is not appreciated for everything that she gave up for our benefit, it affects her more. And I think everything that goes wrong with our lives affects her triple, because I think we are her life. And, you know, I have an aunt who worked all her life, and I see her as emotionally a much healthier person, because she has other things to focus her energies on. And also, now that we are all pretty much grown up and doing our own things, I think my mom feels sort of a void like, "What do I do now?" And so, I think it is important for everyone to have things that they do for themselves and not just for other people.

In a telephone conversation that we had after her initial interview, one law student discussed how she is often wary of men who profess egalitarian views about relationships and claim to respect a woman's career ambitions. She mentioned that she has dated some men who use egalitarian language in their everyday speech but whom she sensed really did not believe that some women are actually committed to having careers, but rather that the women could be coaxed into taking responsibility for family life once they are married and have children. From her point of view, "they just don't get it." Her concerns strike at the heart of the tensions some of these women experienced between what they hoped would happen and what they realistically expect to happen. Given these tensions, ambivalence is to be expected. Furthermore, her fears do not seem unfounded if we con- 
sider, for example, those men who are drawn to career women, yet would ultimately like their wives to stay home with the kids.

One woman in the MBA program, who had been married for several years, discussed how she felt somewhat fortunate that she was about to begin a management career while her husband was not on a formal career track at the time of our interview but was managing some investments from home. Therefore, he would likely be the one to stay home with their newborn for a year or so; however, it appeared from her discussion that he was somewhat reluctant to do so.

Now we are thinking, maybe in a year or two, about having a child. We haven't worked out [child care arrangements], but because he works out of the house a lot, he would probably be more likely to be the one who would be home more often with the kids. . . . But, we haven't really decided because I don't think that's what he wants to do, per se. He really enjoys having his career, and I don't know that he wants to be staying home all the time. But it is an advantage [to have him at home], because at least he could do it for a year or so. It somewhat depends on where my own career heads. But, it's a benefit a lot of people [women] don't have, because oftentimes their husbands are already working somewhere, and fortunately we don't have to worry about that.

\section{EGALITARIAN WOMEN: WEAK FORM}

In contrast to those women who embodied the strong form of egalitarianism, others, who personified the weak form, were interested in having careers but anticipated taking time off and/or cutting back at work during those years when they have young children and, therefore, shifting into more traditional family-based roles. Most of these women did anticipate that making such arrangements would limit their career potential to some extent, and some had already adjusted their career plans accordingly. Their career plans seemed significantly more contingent (as opposed to linear) than those women who reflected strong egalitarian orientations to work and family life. Yet, these women tended to think of themselves as fundamentally egalitarian in their orientations to relationships, not unlike the men in this study who personified a weak form of egalitarianism. Interestingly, the implications in the area of career for the women who embodied weak egalitarianism, as opposed to the men, are quite different, as the women will likely face far more difficult career choices. Having a career was still important for most of the weak egalitarian women, except for the fact that they planned to subordinate career to family life for a number of years. 
One female law student mentioned that she plans to spend her first 5 years out of law school working long hours for a small law firm. Then, if married, she hoped to leave work for a number of years to raise three or four children. Although she viewed herself as being family oriented, her overarching view of marriage was that it must be an equal partnership, except during the time when children are very young; then, she would want to stay home and let her husband be the breadwinner. When asked how she envisioned the way in which she and a future husband would allocate their roles, she replied,

Like they're the same. He works. I work. We help each other. You know, we're friends. I mean, I see me doing just as much as he does. And then when we have kids it just shifts a little. So, I see it as a lot a give and take, and a lot of communication. A partnership really.

She discussed how she would like to stay home with her children until they go to school: "When you send them off to first grade, I think that they are pretty much on their own." So, if she were to have four children, she could end up spending 10 years out of the paid labor force. She was amenable to doing just that.

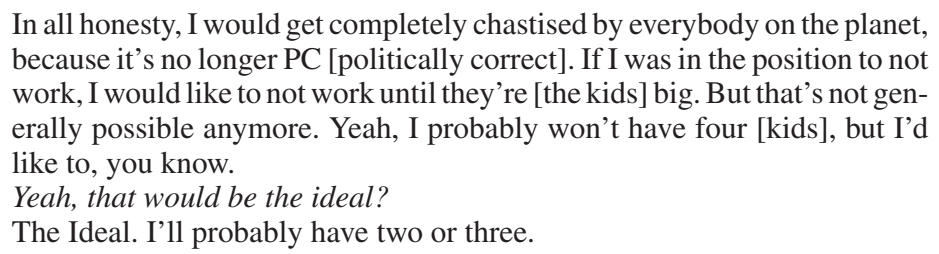

She then mentioned how she might need to work part-time during the period in which she stays home with her children to keep up to date professionally, perhaps a few mornings a week. She had hopes of building up enough expertise before having a family so that her employer might allow her to keep working for the firm, at least on a part-time basis. Ideally, she would rather be able to take time off and spend a few years just raising kids because trying to work and manage family life is like "giving both half and you can't give anything your whole." At the time of our interview, she had accepted an offer from a law firm with which she had served as an intern, and she described how one female lawyer with that firm had arranged her full-time work schedule to accommodate family life. She commented on such a scenario for herself. 
Hopefully, that wouldn't have to happen. . . . [But] there is a lady that I worked with, and she has a 3 -year-old. She goes into the office at 7, and she leaves at 7. She doesn't take a lunch, and she goes full out those 12 hours that she's there, and then she goes home and that is her time with her baby. And I guess you just have to make sacrifices. I mean, that would be something that I would be willing to do.

Another student, who was finishing her degree in law and was seriously involved with a man who was also working on a professional degree, defined similar kinds of plans around work and family life. She discussed how her career plans would be different if she did not expect to have a family some day.

Well, if I didn't want to have a family, raise children, and be there for my spouse one day, I would be interested in a career track with a big law firm. But I steered away from that, knowing that I wanted something else.

She described her vision of marriage as a "loving, trusting, equally supportive relationship where you can be yourself ... a partnership against the rest of the problems of the world." Being a child of divorced parents herself, she emphasized the importance of creating an environment where "children can be themselves;" she said that "children need to know that the family unit is intact." Ideally, she wished to have two or three children and hoped to begin having them a few years out of school. She described her thoughts about how she and her future husband might negotiate work and family roles after having children, and she felt a little embarrassed about her somewhat traditional views.

Well, I don't know if this is good or bad, but it's still a little traditional in that, you know, if I'm going to have kids, I hope to have the opportunity to raise them. And, financially, I might not, you know. I might have to go back to work because dual-income households are like almost mandatory today. So, I just would hope to have the opportunity to stay home as long as I could. So, you would like to maybe take a leave from work?

Take a leave, or go part-time.

For a couple of years?

For a couple of years. I don't see myself never going back, because I'm the type of person who always has [her] hand in something. I see myself working before and up until children and going right back. Umm, I'd like to take a little time off, but financially, you just don't know nowadays. I want [to send] them to college, and buy them clothes. And that's so hard. 


\section{WOMEN: REMAINING SINGLE AS A REALISTIC POSSIBILITY}

Although the vast majority of these women in law and business school planned, or at least aspired, to marry some day, a significant minority of those who expressed this desire also mentioned that they were prepared to remain single, a scenario they considered to be within the realm of the possible, although it was not their ideal. Many seemed to be seriously entertaining single life either in response to the scarcity of available men with whom they might forge egalitarian relationships or in response to the fact that considerations about marriage and family greatly increase the complexity of their own life plans, given that they were committed to staying the course of career over time. Moreover, it seemed as though some of these women were struggling with more traditional notions about women needing relationships, such as marriage, to be happy and fulfilled. In contrast, they seemed to be actively challenging this notion. For these women, however, relationships beyond their immediate family, such as friendships, were identified as those through which they hoped to find the types of support and sense of belonging typically associated with family; some also mentioned parents and siblings as deeply important. ${ }^{7}$

One law student, who mentioned that she would like to have a spouse and, perhaps, children some day but was very committed to her career in public interest law, stated that if she never married, she would probably move near friends. She reflected on the possibility of not marrying.

I don't really know that I'm afraid of being alone. I think that as long as I'm doing things, planning my life around this idea that there is going to be someone else [in my life]. Right now, I'm planning my life as to what makes me happy, while doing something that makes me feel productive.

She also emphasized the importance of maintaining strong ties with her close friends, even though they may end up living in different parts of the country: "I always make time for my friends, because they are like family to me. I don't just work, work, work! My relationships are very important to me."

Along similar lines, one MBA student, described above as a strong egalitarian who ideally hoped to alternate responsibility for taking care of young children with a future spouse someday but felt her goal was unrealistic, also entertained the possibility of remaining single. When asked if she could imagine herself not getting married someday, she replied, "Can I imagine it? Yeah. I mean that would not be my ideal, but I wouldn't be devastated by it." We discussed how her mother's extended family were an important part of her life and would likely remain so. Furthermore, on being asked about whether should would seek to forge other family-like rela- 
tionships should she not marry, she responded that she had a group of friends who already filled that need and emphasized that she might even decide to have children on her own.

I already have a group of close friends that I call my second family. No question. A very definite group and they fill a lot of that now.... I don't think it's absolutely certain that I have to be married to have children. I might feel that way - that I want to have a child, period.

Another MBA student, who also described her ideals for a relationship in strong egalitarian terms, discussed how she was planning to move near a group of old friends after graduating from business school. These friends have been like distant family to one another over the years, and she expects to remain in close proximity to them throughout her working life. She also mentioned having close relationships with both of her parents, who divorced when she was an adolescent. Although she would ideally like to have a strong egalitarian relationship with a husband and start a family someday, she also mentioned that if she was not married by age 35 , she thought about having, or perhaps adopting, a child and being a highly involved parent. It seems that having a close community of friends, not to mention a professional salary, might provide the kind of supportive environment in which she would consider having a child, should she not marry.

These friends have always been [at the] core of my life.... I've moved away from them. ... I think we have had the unique experience of a lot of childhood friends who, despite our interests changing and our lives changing, have remained close and supportive of each other. And because of that, they are my core. And when I get busy, I forget that. That's one of the reasons I want to get back to [names city], because I want to be centrally located near them ... that's so important to me.

Another woman talked about her work habits and how she felt that work was strongly tied into her identity, to the point that it could make it difficult to develop a relationship with a partner some day. She hoped that whenever the time came, she would take the time and put the effort into a relationship; yet, she seemed to have defined a fairly linear as opposed to contingent set of career plans over the next decade or so.

[Work] is something that is very important to me and, I guess, probably defines how I think about myself on a lot of levels such that, yes, it will definitely impact a relationship. . . I assume that when I do meet the person who is at least right for an extended period of time, I suspect that I will rec- 
ognize that at some point during that time frame and be willing to commit more to that.

She described the kind of relationship she would like to have with a future partner as one in which they are "both working," and one with an "equitable contribution between my husband and myself" when it comes to making a commitment to raising children. She said she has also considered the possibility of adopting a child or having one on her own some day, although it is not her ideal: "I could also see myself as a single mother. That would be something I would feel comfortable doing."

Like the other women who considered remaining single and having children on their own as a realistic alternative to having a partner, she also discussed how friends were important in her life, but she was wary about holding expectations that friends would always be around. Not unlike these other women, she expected to maintain close ties with her family of origin.

Oh yeah. I'm very close with my immediate family, my parents and my two sisters. And although I like to be alone in my leisure time fairly regularly because it's my only chance to reconnect with myself, I definitely need that [friends/family] in my life, because I lean on other people to provide support.

So, do you think friends could become like family?

Yeah. The problem there is that when all of your friends start to get married, then they go away. But, I definitely need that from some source in my life.

But, in general, you expect you will get married and have kids some day?

Yeah. It will happen, so I'm told [laughs].

\section{SUMMARY/CONCLUSIONS}

This study examined how a group of advanced law students and MBAs in the anticipatory stage of the life course conceptualize their plans for work and family life, looking ahead roughly 5 to 7 years. It sought to capture the complex ways in which these aspiring professionals envision their own personal futures by relying on in-depth analysis of their definitions of the situation. From this in-depth analysis, it can be seen how respondents' thoughts, hopes, and anxieties about the future affect the ongoing process of life planning as it is carried out in the present and vice versa. Furthermore, it is through an examination of this active process of anticipating and planning for the future that we can see how respondents' accounts fit with the thematic types presented. In focusing on their personal defini- 
tions of the future, this research has sought to capture respondents' gender role orientations in a comprehensive and dynamic way, and it should supplement those studies that are focused more narrowly on gender-role attitudes or beliefs-which may or may not be well integrated into the active and ongoing processes of mapping out one's future.

The findings presented herein point to a certain degree of asymmetry between men and women with regard to their views of equality. On the one hand, the dominant orientation among the men was toward a modified form of providing. Among all of the respondents, providers exhibited the most linear and segmented plans for their own futures, in that they identified strongly with having careers and providing financial security for their families, but they also seemed to value the more expressive aspects of family life, such as having warm and close relationships with their future spouses and children. On the other hand, the dominant segment of the women reflected a strong egalitarian orientation toward work and family life, in that they planned to pursue careers and have families and also sought to find spouses who would equitably share in both the rewards and responsibilities associated with careers and family life. Their plans for the future were somewhat more contingent and synergistic than those of the men, however, because they actively grappled with issues involved in balancing work and family life, issues that were incorporated into their definitions of the future. Other minority segments of the men and the women identified with a weak form of egalitarianism, which would likely involve shifting into more traditional breadwinner-homemaker roles with their future spouses during those times when young children are present. There was also a small segment of men who identified with a strong form of egalitarianism. A small segment of women identified with a strong form of egalitarianism, yet they also entertained the possibility of remaining single and cultivating family relationships with close friends or relatives.

Although the thematic types developed in this study reflect these aspiring professionals' orientations toward work and family life, this research also underscores how these orientations often reflect tensions that respondents confront (in an ongoing manner) between their hopes and expectations. Furthermore, these tensions generate a good measure of ambivalence for these professional school students. For example, some of the women who were oriented toward strong egalitarian relationships experienced ambivalence about their plans for the future as they considered the possibility that their future partners might not share work and family opportunities and responsibilities equitably with them. In contrast, some of the providers seemed ambivalent about their future wives pursuing ca- 
reers, in that they supported such activities in the abstract but experienced conflict or tensions as they considered real possibilities of how their own lives with real partners might actually play out, given such arrangements. Ultimately, however, respondents seemed to take a more pragmatic as opposed to ideological approach toward resolving issues surrounding work and family life, as they grappled with the contingency and complexity of their own futures.

Although the seeming asymmetry between men and women in their views of equality represents an important problem, we must also be mindful of the broader employment context in which these men and women define their orientations toward work, family, and the future. The rigidities inherent in career trajectories for professionals have made it difficult for couples to find creative ways of balancing work and family commitments. For instance, the risks involved for both men and women of getting "off track" in career can be substantial (in spite of the fact that there are few clearly defined tracks to follow within the modern corporation). Moreover, the uncertainties associated with contemporary careers can discourage those couples who may seek to share career opportunities as well as family responsibilities in an equitable manner from doing so, because of the potentially deleterious financial consequences associated with placing the male breadwinner role at risk. In contrast, many of the female respondents in this study, who like their male colleagues enjoy the advantages associated with a high-quality professional school education, hope to leverage their expertise and skills to negotiate flexible arrangements with their employers when they plan to have children. But many of them seem to anticipate that their work environments will be highly competitive and therefore are wary about the long-term financial and perhaps developmental risks involved in cutting back at work.

This research reveals substantial gender differences among professional school students with respect to their orientations toward work, family, and equality. We need more in-depth research focusing on how recent graduates make the transition into the workplace and family life, paying special attention to those institutional contexts most supportive of couples who attempt to successfully blend their career and family aspirations with a sense of equal concern and respect.

\section{NOTES}

1. Recent manifestations of the long-term rise of individualism represent one deeply significant transformation within American life and led to key sociological debates during 
the 1980s that were focused primarily on a generation of baby boomers. Perhaps one of the most influential critiques of the new individualism was put forth by Bellah, Madsen, Sullivan, Swidler, and Tipton $(1985,1991)$. They decried the recent evolution of Lockean style individualism in both its contemporary utilitarian and, especially, expressive forms, which they viewed as severe threats to committed relationships and the maintenance of a civil society. Other critics leveled similar critiques of the new individualism, decrying the new narcissism (Lasch, 1978) or warning about the "new rules" associated with the rise of an emerging therapeutic ethic (Yankelovich, 1981). On the other hand, others such as Cancian (1987) argued against the critics of this new individualism by asserting that the trend toward self-development actually provided the means for building and strengthening committed relationships for those who followed a blueprint based on interdependence.

2. Downsizing and restructuring have increasingly become accepted practices in the corporate world since the 1980s. Much of this activity has been in response to mergers and takeovers, which had become commonplace by the mid-1980s as part of a general economic restructuring that has led to profound changes in the nature of professional work in America. Two of the most significant transformations associated with restructuring and downsizing have been the reduction of internal career ladders within the corporation, along with growing mistrust on the part of their employees. As a result, there has been growing consensus over the past decade that remaining loyal to one's corporate employer is unwise (Farnham, 1989; Hirsch, 1987; Kanter, 1989; Kotter, 1995). In this new environment, individuals are advised to look not for companies that provide long-term job security, per se, but instead for jobs that offer "employability security ... the knowledge that today's work will enhance the person's value in terms of future opportunities" (Kanter, 1995, p. 157).

3 . In addition, the complex nature of defining the future represented a key theoretical issue to be addressed, given the potential contingencies of life planning that have emerged in conjunction with these transformations. Drawing on the early work of W. I. Thomas and his definition of the situation, the work of several key social theorists - situated directly or indirectly within the tradition of Thomas-were used to extend this concept to the study of the future. Thomas's (1970) notion of the life policy, Mead's (1932) philosophy of the present, Berger, Berger, and Kellner's (1973) notion of the life plan, and MacIver's (1942) dynamic assessment were all instrumental in conceptualizing how actors define the future, as well as how their definitions illuminate gender-based assumptions that guide the unfolding of one's life plans.

4. Pleck (1983) has argued that this emphasis on expressive relations may provide the basis for expanding their involvement in family roles. On the other hand, research must be sensitive to LaRossa's (1988) important caveat that over the course of the 20th century, the culture of fatherhood - as opposed to the conduct of fatherhood-has changed to reflect more involved parenting on the part of fathers.

5. For example, during the time that I was conducting interviews for this research project, Fortune magazine (see Morris, 1997) ran a cover story titled, "Is Your Family Wrecking Your Career? (and Vice Versa)." In addition, Time ran a major story about "The Myth of Quality Time" (Shapiro, 1997).

6. Furthermore, the reporting of findings from qualitative research in the social sciences involves rectifying the tensions between two very different kinds of approaches. At one extreme are those that allow respondents to speak for themselves and tell their own stories. In those cases, the researcher's role is to refrain from interfering with the telling of those stories (cf. Lewis, 1963). At the other extreme are those that merely present analysis supplemented by few if any quotes from respondents (cf. Stack, 1974). This research follows Williams (1990), who defines a middle way whereby the researcher provides analysis through some 
interpretive framework yet allows for ample use of quotes, and these serve to highlight how the researcher's own framework provides a bridge between the meanings or "definitions of the situation" provided by the respondents themselves and some deeper set of theoretical issues (cf. Rubin, 1976).

7. These women are not unlike one segment of those described by Hertz and Ferguson (1998): single mothers with substantial financial resources.

\section{REFERENCES}

Andrews, A., \& Bailyn, L. (1993). Segmentation and synergy: Two models of linking work and family life. In J. Hood (Ed.), Men, work, and family (pp. 262-75). Newbury Park, CA: Sage.

Barnett, R., \& Rivers, C. (1996). He works, she works. New York: Harper Collins.

Becker, P., \& Moen, P. (1999). Scaling back: Dual-earner couples' work-family strategies. Journal of Marriage and the Family, 61, 995-1007.

Bellah. R., Madsen, R., Sullivan, W., Swidler, A., \& Tipton, S. (1985). Habits of the heart. Berkeley and Los Angeles: University of California Press.

Bellah. R., Madsen, R., Sullivan, W., Swidler, A., \& Tipton, S. (1991). The good society. New York: Knopf.

Berger, P., Berger, B., \& Kellner, H. 1973. The homeless mind: Modernization and consciousness. New York: Vintage.

Bernard, J. (1981). The good provider role: Its rise and fall. American Psychologist, 36(1), $1-12$.

Bielby, W., \& Bielby, D. (1989). Family ties: Balancing commitments to work and family in dual-earner households. American Sociological Review, 54(5), 776-789.

Cancian, F. (1987). Love in America: Gender and self-development. Cambridge, UK: Cambridge University Press.

Cohen, T. (1993). What do fathers provide? Reconsidering economic and nurturant dimensions of men as parents. In J. Hood (Ed.), Men, work, and family (pp. 1-22). Newbury Park, CA: Sage.

Farnham, A. (1989, December 4). The trust gap. Fortune, pp. 56-76.

Gerson, K. (1985). Hard choices: How women decide about work, career, and motherhood. Berkeley: University of California Press.

Gerson, K. (1993). No man's land: Men's changing commitments to family and work. New York: Basic Books.

Han, S. K., \& Moen, P. (1999, March). Work and family over time: A life course approach. Annals of the American Academy of political and social science, 562, 98-110.

Hertz, R., \& Ferguson, F. (1998). Only one pair of hands: Ways that single mothers stretch work and family resources. Community, Work, \& Family, 1(1), 13-37.

Hirsch, P. (1987). Pack your own parachute. New York: Addison-Wesley.

Hochschild, A. (1989). The second shift. New York: Avon.

Hochschild, A. (1997). The time bind: When work becomes home and home becomes work. New York: Metropolitan.

Hood, J. (1986). The provider role: Its meaning and measurement. Journal of Marriage and the Family, 48, 349-359.

Kanter, R. (1989). When giants learn to dance. New York: Simon \& Schuster. 
Kanter, R. (1995). World class: Thriving locally in the global economy. New York: Simon \& Schuster.

Kotter, J. (1995). The new rules: How to succeed in today's post-corporate world. New York: Free Press.

Lamont, M. (1992). Money, morals, and manners: The culture of the French and American upper-middle class. Chicago: University of Chicago Press.

LaRossa, R. (1988). Fatherhood and social change. Family Relations, 37, 451-457.

Lasch, C. (1978). The culture of narcissism: American life in an age of diminished expectations. New York: Norton.

Lewis, O. (1963). Children of Sanchez. New York: Random House.

MacIver, R. (1942). Social causation. New York: Harper Torchbooks.

Maines, D., \& Hardesty, M. (1987). Temporality and gender: Young adults career and family plans. Social Forces, 66, 102-20.

Mead, G. (1932). The philosophy of the present. Chicago: Open Court.

Moen, P. (1992). Women's two roles: A contemporary dilemma. New York: Auburn House.

Moen, P., \& Wethington, E. (1992). The concept of family adaptive strategies. Annual Review of Sociology, 18, 233-251.

Morris, B. (1997, March 17). Is your family wrecking your career? (and vice versa). Fortune, pp. 71-90.

Pleck, J. (1983). Husband's paid work and family roles: Current research issues. In H. Lopata \& J. Pleck (Eds.), Research into the interweave of social roles: Families and jobs (Vol. 3, pp. 251-333). Greenwich, CT: JAI Press.

Pleck, J. (1993). Are "family-supportive" employer policies relevant to men? In J. C. Hood (Ed.) Men, work, and family (pp. 217-37). Newbury Park, CA: Sage.

Rubin, L. (1976). Worlds of pain. New York: Basic Books.

Schwartz, P. (1994). Peer marriage: How love between equals really works. New York: Free Press.

Shapiro, L. (1997, May 12). The myth of quality time. Newsweek, pp. 62-69.

Shelton, B., \& John, D. (1996). The division of household labor. Annual Review of Sociology, 22, 299-322.

Spain, D., \& Bianchi, S. (1996). Balancing act. New York: Russell Sage Foundation.

Stack, C. (1974). All our kin. New York: Harper \& Row.

Thomas, W. (1970). The definition of the situation. In L. Coser \& B. Rosenberg (Eds.), Sociological theory: A book of readings. London: Macmillan.

Wallace, P. (1989). MBAs on the fast track: Career mobility of young managers. New York: Ballinger.

Williams, N. (1990). The Mexican American family: Tradition and change. Dix Hills, NY: General Hall.

Wolfe, A. (1998). One nation after all. New York: Viking.

Yankelovich, D. (1981). New rules. New York: Random House. 